\title{
Comparison of the Opinions of Citizens and Professional Soccer Players about Betting and Match Fixing
}

\author{
Faruk Salih Şeker ${ }^{1, *}$, Mehmet Şahin ${ }^{2}$ \\ ${ }^{1}$ School of Applied Sciences, Istanbul Ayvansaray University of Istanbul, Turkish Republic \\ ${ }^{2}$ School of Sports Science Faculty, Istanbul Gedik University of Istanbul, Turkish Republic
}

Received April 20, 2020; Revised July 3, 2020; Accepted July 20, 2020

\section{Cite This Paper in the following Citation Styles}

(a): [1] Faruk Salih Şeker, Mehmet Şahin, "Comparison of the Opinions of Citizens and Professional Soccer Players about Betting and Match Fixing," International Journal of Human Movement and Sports Sciences, Vol. 8, No. 4, pp. 110-116, 2020. DOI: 10.13189/saj.2020.080402.

(b): Faruk Salih Şeker, Mehmet Şahin (2020). Comparison of the Opinions of Citizens and Professional Soccer Players about Betting and Match Fixing. International Journal of Human Movement and Sports Sciences, 8(4), 110-116. DOI: 10.13189/saj.2020.080402.

Copyright $\odot 2020$ by authors, all rights reserved. Authors agree that this article remains permanently open access under the terms of the Creative Commons Attribution License 4.0 International License

\begin{abstract}
The aim of this study is to compare the impacts of match fixing on citizens who play the betting game İddaa and professional soccer players. More specifically, how match fixing related to betting is affecting social morality. Sports is a part of social morality and one of the sub-aims of this study is to evaluate the chaotic interactions that emerge from the mixing of the sports and betting, and the betting and match fixing. Survey methodology was used. The research universe consisted of betting game players and professional footballers in Turkey. Betters playing the İddaa betting game in İddaa dealers located in the cities of 2010-2011 Turkish Super League soccer teams and professional soccer players were considered as the target audience. A total of 1637 İddaa betting citizens and 115 professional soccer players took part in the survey. In the questionnaire with 26 questions, four questions are intended to examine the biographical features, four are intended to examine the characteristics of playing the İddaa game, and the remaining 18 are intended to examine the effects on social morality. The questions were asked to the people who played İddaa game without any biographical distinction. As a result, both betters and soccer players agree that match fixing in soccer quickly directed "those who want to make easy money" towards the betting industry. While citizens were indecisive about the opinion "professional soccer players are extremely uncomfortable with match fixing", soccer players agreed with it. The difference on this opinion between citizens and soccer players is statistically significant.
\end{abstract}

Keywords Betting, Match Fixing, Professional Soccer Player, Citizen

Note: The data of the citizens used in this study are taken from Faruk Salih Şeker's the master thesis of "The Communal Effects of Bet Match Fixing in Football".

\section{Introduction}

This study was conducted to investigate how match fixing in football affects society morally and financially. For this purpose, 1637 citizens were surveyed with coincidence method from 13 cities in which 2010-2011 Spor Toto Super League games were played. Also, 115 professional soccer players who played in 2010-2011 Spor Toto Super League and Turkey Bank Asia 1st League were surveyed. In the questionnaire with 26 questions, four questions are intended to examine the biographical features, and four are intended to examine the characteristics of playing the İddaa game, and the remaining 18 are intended to examine the effects on social morality. These questions were applied to the people who played İddaa game without any biographical distinction. The difficulties we encountered when we started to work, the longing for sports ethics, ambivalent attitude of people from all walks of sports even though everyone knows that something is wrong has led us to conduct such a study. 
For centuries, there have been people seeking unfair profits. One of the places where unfair earnings have been achieved has been the sports industry in general and the soccer industry in particular. People have searched for corrupted ways to make money from this game in order to earn a lot of money with little effort. No adjective has prevented this corruption. Managers, technical staff, footballers, sponsors and even fans who fell in love with the colors of their teams are included in this dirty game [1].

The first live betting company of the world Bettson was founded in Malta in 2001. It is a Swedish based company and opened its first branch in Sweden. Betsson entered the Turkish market in 2004. The company has received the support of European banks and its stocks have been sold on the stock exchange in Stockholm [2].

Even though there are no written sources, it is known that illegal bets in Turkey have started with animal owners who participated in cruel bloodsports such as camel fighting, dog fighting and cock fighting. The first legal betting game was played in 26 March 1960. Ulvi Yenal, President of the Football Federation in that period, was quoted saying "Betting is not common gambling. It is a prediction and information based competition. It increases enthusiasm for football. In addition, the necessary revenue is obtained for sports facilities. In this way, new facilities and new fields are built. It is an opportunity for a larger audience to engage in sports."[3].

As the amount of money unfairly earned through illegal ways increased, it attracted the attention of states, and gambling, namely betting, changed its name to "betting game" by legal means. Betting games, which have evolved with the development of technology from the past to the present, have been played under the auspices of the state in order to transfer the earnings from illegal betting games to the state treasury until the procurement in 2019. Yildirım Demirören, the chairman of the group that won the bidding for the procurement, had been the president of the Turkish Football Federation (TFF) for seven years. He said "I am resigning the Presidency of Turkish Football Federation which I have occupied since 26 February 2012 due to the transfer of iddaa.com and misli.com to Demirören Holding and the legal completion of the transfer of the contracts" $[4,5]$. What could be the reason that Demirören chose betting games over the Presidency of Turkish Football Federation?

Football, which has been getting popular over the years, has had a big share in the world economy with the developing technology and has strengthened its power with betting games [6]. With the advancing of technology making easy money is no longer limited to betting only. Match fixing has made its name not only in the world of football, but in all sports. Match fixing can be thought of as influencing the outcome of a sports match for financial or non-financial reasons and/or playing a prearranged sports match, and it has many flavors such as match fixing by parties, match fixing as a favor, match fixing with referees (bribery), match fixing without profit, and match fixing with the participation of non-sports elements $[7,8]$.

\section{Materials and Method}

In this research, the survey technique, one of the quantitative research methods, was used. All participants voluntarily participated in this research [9]. The study was designed to examine the social effects of the match fixing scandal, which shook Europe, in our country and the reaction it created by comparing the opinions of the betting game players and professional footballers. A questionnaire was prepared to gather data for this purpose. Survey instrument was made in consultation with the expert advisors who are Professor Dr. Mustafa SAATÇİ, Assoc. Prof. Dr. Hakan ÖNER and Asst. Prof. Dr. Hülya ŞAHIN. The pre-test and post-tests of the questionnaire were implemented to 50 students playing İddaa game in the School of Sport. There is one-week interval between pretest and posttest implementation. Validity and reliability of the instrument were tested.

1637 citizens were surveyed with coincidence method from 13 cities in which 2010-2011 Spor Toto Super League games were played. These cities are İstanbul, Trabzon, Eskişehir, Sivas, Bursa, Ankara, Gaziantep, Kayseri, Karabük, Mersin, Ordu, Antalya, Manisa and Samsun. Those playing İddaa game were seen as the target audience. A questionnaire was implemented to people in the places where the IDDAA game was played. İddia shops in 13 provinces were chosen from the busiest and shop owners accepted the survey implementations. Surveys have been implemented from morning to evening in each shop on Fridays or Saturdays, the days when the game was played the most. It was applied to people who volunteered to participate in the survey in the İddia Shops. And random sampling method was used to select the participants of the study group. Also, 115 professional soccer players who played in 2010-2011 Spor Toto Super League and Turkey Bank Asia 1st League were surveyed. These consist of teams that come to the winter camp in Belek, Antalya. Appointments were requested at the hotel where the football teams stay. A questionnaire was implemented to the volunteer footballers. 115 professional football players completed the questionnaire. This number is not higher due to the number of teams coming to the second half winter camp in Belek, the administrators' disapprovements of the participation in the survey, and football players who are not willing to participate in the survey. In the questionnaire with 26 questions, four questions are intended to examine the biographical features, four are intended to examine the characteristics of playing the İddaa game, and the remaining 18 are intended to examine the effects on social morality. These questions were applied to the people who played İddaa game without any biographical distinction. In addition, professional footballers and citizens participated 
in this study voluntarily. SPPS 21.0 for Windows was used to analyze the gathered data. One-Sample Kolmogorov-Smirnov test was used to test for normality of the data. Due to the non-normal nature of the data non-parametric Mann-Whitney $U$ test was used for comparison the groups. Frequency analysis was performed to determine the percentage distribution of age and gender variables. Missing values were ignored in all analyzes.

\subsection{Descriptive Statistics}

Most of the citizens participated in this study were between 19-24 years old $(43.3 \%, \mathrm{f}=709)$. Most of the professional footballers participated in this study were between $19-30$ years old $(77.4 \%, \mathrm{f}=89)$.

$85.6 \%$ of the citizens were males and $14.4 \%$ were females. All of the footballers were males.

\section{Findings}

Table 1. Mean values and standart deviations of the variables

\begin{tabular}{|c|c|c|c|c|c|c|c|c|c|c|c|}
\hline \multicolumn{6}{|c|}{ Citizen } & \multicolumn{6}{|c|}{ Professional Footballer } \\
\hline${ }^{*}$ Variable & $\mathbf{N}$ & Min & Max & $\mathbf{M}$ & SD & *Variable & $\mathbf{N}$ & Min & Max & $\mathbf{M}$ & SD \\
\hline 1 & 1637 & 1 & 5 & 2,26 & 0,994 & 1 & 51 & 1 & 5 & 2,62 & 1,280 \\
\hline 2 & 1637 & 1 & 5 & 2,34 & 1,452 & 2 & 11 & 1 & 4 & 1,45 & 0,934 \\
\hline 3 & 1637 & 1 & 3 & 2,20 & 0,846 & 3 & 114 & 1 & 3 & 2,05 & 0,839 \\
\hline 4 & 1637 & 1 & 2 & 1,46 & 0,498 & 4 & 56 & 1 & 2 & 1,64 & 0,483 \\
\hline 5 & 1637 & 1 & 2 & 1,90 & 0,296 & 5 & 78 & 1 & 2 & 1,97 & 0,159 \\
\hline 6 & 1637 & 1 & 3 & 1,57 & 0,728 & 6 & 114 & 1 & 3 & 1,32 & 0,602 \\
\hline 7 & 1637 & 1 & 3 & 1,76 & 0,808 & 7 & 114 & 1 & 3 & 1,27 & 0,568 \\
\hline 8 & 1637 & 1 & 3 & 1,52 & 0,735 & 8 & 115 & 1 & 3 & 1,88 & 0,855 \\
\hline 9 & 1637 & 1 & 3 & 1,47 & 0,736 & 9 & 115 & 1 & 3 & 1,40 & 1,106 \\
\hline 10 & 1637 & 1 & 3 & 1,98 & 0,877 & 10 & 87 & 1 & 3 & 1,71 & 0,819 \\
\hline 11 & 1637 & 1 & 3 & 1,65 & 0,783 & 11 & 112 & 1 & 3 & 1,82 & 1,785 \\
\hline 12 & 1637 & 1 & 3 & 1,89 & 0,885 & 12 & 86 & 1 & 3 & 2,54 & 0,776 \\
\hline
\end{tabular}

M: Mean; SD: Std. Dev.;

Table 2. Mann Whitney U test

\begin{tabular}{lcc}
\hline \multicolumn{1}{c}{ Variables } & Mann-Whitney & U \\
\hline Where do you follow the betting games? & 35146,00 & 0,041 \\
What is the average number of times you play betting games in a month? & 5734,00 & 0,030 \\
Match fixing news in the media has reduced the interest in betting games. & 84037,50 & 0,049 \\
Is there anyone around you who won a large amount of money playing betting games? & 37470,00 & 0,009 \\
Is there anyone around you who play betting games and won money through match fixing? & 59279,00 & 0,034 \\
Club administrations are disturbed by the match fixing incident that occurred in other clubs? & 76499,50 & 0,000 \\
Professional footballers are extremely uncomfortable with match fixing. & 62073,00 & 0,000 \\
Some professional footballers place bets on the matches that they play in. & 72523,00 & 0,000 \\
Match fixing in betting games shows the decay in social morality. & 84547,00 & 0,027 \\
My interest in betting games such as İddaa has decreased after I had learned about the match fixing. & 59200,50 & 0,005 \\
Betters are disturbed by the notion of match fixing. & 80491,00 & 0,017 \\
I play betting games even though I am aware of the match fixing & 43111,50 & 0,000 \\
\hline
\end{tabular}


*1: Where do you follow the betting games, 2 : What is the average number of times you play betting games in a month, 3: Match fixing news in the media has reduced the interest in betting games, 4: Is there anyone around you who won a large amount of money through playing betting games, 5: Is there anyone around you who plays betting games and wins money through match fixing, 6: Club administrations are disturbed by the match fixing incidents that occurred in other clubs, 7: Professional footballers are extremely uncomfortable with match fixing, 8: Some professional footballers place bets on the matches that they play in, 9: Match fixing in betting games shows the decay in social morality, 10: My interest in betting games such as İddaa has decreased after I had learned about the match fixing, 11: Betters are disturbed by the notion of match fixing, 12: I play betting games even though I am aware of the match fixing.

There is a significant difference between citizens and footballers in where they prefer to follow the betting games $(\mathrm{U}=35146.00 ; \mathrm{p}<0.05)$. While the citizens follow the games from newspapers (Mean: 2.26), professional footballers follow them on internet (Mean: 2.62).

When monthly average of playing betting games is examined, a significant difference is observed between citizens and footballers $(\mathrm{U}=5734.00 ; \mathrm{p}<0.05)$. Citizens play 5-8 betting games monthly on average (Ort: 2.34), footballers play 1-4 games (Mean: 1.45).

There is a significant difference between the citizens and footballers in the opinion that match fixing news in the media has reduced the interest in betting games $(U=84037.50 ; p<0.05)$. In contrast to citizens, footballers think the match fixing news on the media did not reduce the interest in betting games (Mean: 2.20, Mean: 2.05).

A significant difference between citizens and footballers was observed in whether they know someone in their social environment who won large amounts of money playing betting games $(\mathrm{U}=37470.00 ; \mathrm{p}<0.01)$. It is observed that citizens know more people who won large amounts of money by playing betting games than footballers (Mean: 1.64, Mean: 1.46).

There is a significant difference between citizens and professional football players in whether there is someone in their social environment who won bets by match fixing $(\mathrm{U}=59279.00 ; \mathrm{p}<0.05)$. In contrast to citizens, professional football players knew people around who won bets by match fixing (Mean: 1.97, Mean: 1.90).

Examining the perception that club administrations are disturbed by the match fixing incidents in other clubs, citizens and footballers showed a significant difference $(\mathrm{U}=76499.50 ; \mathrm{p}<0.01)$. Unlike citizens, professional footballers think that club administrations are disturbed by match fixing incidents in other clubs (Mean:1.57; Mean:1.32).

There is a significant disagreement between citizens and footballers on the opinion that professional footballers are extremely disturbed by match fixing ( $U=62073.00$; $\mathrm{p}<0.01$ ). Contrary to citizens, professional footballers do not think that professional footballers are extremely disturbed by match fixing (Mean: 1.76, Mean: 1.27).

When the perception that some professional footballers place bets in matches that they play in is examined, a significant difference between citizens and professional footballers is observed $(U=72523.00 ; p<0.01)$. Unlike footballers, citizens disagree with the opinion that some professional footballers place bets in matches that they play in (Mean: 1.88, Mean: 1.52).

There is a significant difference between citizens and professional footballers in the opinion that match fixing in betting games is an indicator of the decay in social morality $(\mathrm{U}=84547.00 ; \mathrm{p}<0.027) . \quad$ In contrast to citizens, professional footballers agree that there is a decay in social morality (Mean: 1.47, Mean: 1.40).

When examining whether they have lost interest in betting games after they had learned about the match fixing, citizens and professional footballers show a significant difference $(\mathrm{U}=59200.50 ; \mathrm{p}<0.05)$. Unlike footballers, citizens' interest in betting games decreased (Mean: 1.71, Mean: 1.98).

When the perception that betters are disturbed by the notion of match fixing is analyzed, it is seen that there is a significant difference between citizens and professional football players $(U=80491.00 ; p<0.05)$. It is observed that citizens are more disturbed than professional football players (Mean: 1.65, Mean: 1.82).

When asked whether they would keep playing betting games even though they are aware of the match fixing, a significant difference between citizens and professional footballers is observed $(\mathrm{U}=43111.50 ; \mathrm{p}<0.01)$. Unlike professional footballers, citizens keep playing betting games even though they know about the match fixing (Mean: 2.54, Mean: 1.89).

There were no significant differences between the groups about the answers to the questions $(\mathrm{p}>0.05)$ : "On average, how much do you bet in a month?", "Is there anyone around you who played betting games and got into an economic deadlock?", "Match fixing in soccer has quickly directed 'those who want to make easy money' towards the betting industry.", "Match fixing news on media have popularized the betting games.", "Betting games have caused psychological crisis.", "Match fixing news on media have increased the interest in betting games.", "My interest in sports has decreased after I had learned about match fixing.", "It is very hard to win at betting games without getting tips.".

\section{Results and Discussion}

Ultimately, the aim of this study was to examine the perspectives of betting game playing citizens and professional footballers in Turkey about the match fixing scandal. Independent variables such as age, occupation, monthly income, education, marital status and gender see 
the match fixing as an insignificant detail when it comes to betting in football.

It is observed that citizens follow the betting games from newspapers and professional footballers follow the betting games on the internet. On average, citizens play 5-8 betting games in a month while footballers play 1-4 betting games. It is stated in TFF Disciplinary Instructions Article 57 Betting [10]

(1). Persons covered by this instruction;

a. Are forbidden to play direct or indirect betting games or similar games of chance on football matches and/or any activity about football.

b. Cannot directly or indirectly hold any duties or interests in businesses, organizations and institutions (other than public institutions and organizations) that promote, mediate, organize or perform betting or similar games of chance or similar events or transactions related to football competitions.

(2). Those who act against are punished by dismissal from competitions or deprivation of rights for a duration of three months to a year.

This study reveals that there are professional footballers who play betting games. This could be attributed to the excitement, enjoyment from the betting games, addiction, and the desire to earn more money. However, the next step from the desire to win is to fix matches. The insufficiency of the precautions taken or the punishments against professional footballers playing betting games shows the inadequacy of the TFF. "Sports violence law" with the number 6222 was prepared and enacted by Republic of Turkey for the prevention of disorder and violence in sports in 2004. However, this law was revised in 2012, because it did not meet the needs $[11,12]$. Legal processes (judicial proceedings) in Turkey revealed that in football match-fixing. Fenerbahçe Club President, national footballers and referees were punished and held. Match-fixing in Turkey have been proved. Many people who are interested in sports and İddia game have less interest in football and İddia game [13,14].

Match-fixing is not only in Turkey. There are also match-fixing in Europe in many countries, especially in Belgium, Italy, France, Germany and in Asia, especially in Cambodia [15-17]. The spread of betting games also caused the spread of match-fixings. Football has lost its essence. Football has become a vehicle for betting and match-fixing. This is exactly our subject of discussion.

It has been observed that citizens know people in their social environment who won large amounts of money by playing betting games. This is in contrast to professional footballers. Furthermore, it has been observed that unlike professional footballers, citizens know people in their social environment who won betting games by match fixing.

Examining the perception that club administrations are disturbed by the match fixing incidents in other clubs, citizens and footballers showed a significant difference. Contrary to citizens, professional footballers think that club administrations are disturbed by the match fixing incidents in other clubs.

There is a significant disagreement between citizens and footballers on the opinion that professional footballers are extremely disturbed by match fixing. Contrary to citizens, professional footballers do not think that professional footballers are extremely disturbed by match fixing. When the perception that some professional footballers place bets in matches that they play in is examined, a significant difference between citizens and professional footballers is observed. Unlike footballers, citizens disagree with the opinion that some professional footballers place bets in matches that they take part in. It is understood that professional footballers and citizens who bet are aware of the match fixing. However, despite their knowledge, their ambition to take part in a rigged organization and earn money continued.

When the match fixing in betting games and the decay in social morality are examined, contrary to citizens, professional footballers think that there is a decay in social morality. When the question whether there is a reduction in the interest to betting games after learning about the match fixing is examined, it is observed that citizens lost more interest than the professional footballers. When the perception that betters are disturbed by the notion of match fixing is examined, citizens are observed to be more disturbed than professional footballers. When whether they would keep playing betting games even though they are aware of the match-fixing is examined, a significant difference between citizens and professional footballers is observed. Unlike professional footballers, citizens keep playing betting games even though they know about the match fixing.

In the study of Hanbay (2012), 80\% of the participants thought that there was match fixing in football. This finding supports our study. In the same study, the most trusted institution was found to be TFF. When the year of the study and the fact that the new owner of the İddaa betting game was the president of TFF for 7 years is considered, would a newer study find that the most trusted institution is still TFF?

When asked: "On average, how much do you bet in a month?", "Is there anyone around you who played betting games and got into an economic deadlock?", "Match-fixing in soccer has quickly directed "those who want to make easy money' towards the betting industry.", "Match fixing news on media have popularized the betting games.", "Betting games have caused psychological crisis.", "Match fixing news on media have increased the interest in betting games.", "My interest in sports have decreased after I had learned about match fixing.", and "It is very hard to win at betting games without getting tips." citizens and professional footballers did not show significant differences. 
Ceylan's study shows that the relationships between football and politics, and between football and media reveal the tremendous financial and emotional power of football. The desire to be in the front rows and the need for the support of the society are always relevant in politics. However, the relationship between football and politics has revealed many problems. The biggest problem is that football is deeply embedded in nationalism. A sport that is already competitive in essence becomes violent due to extreme nationalism. Politics alone exploits the spiritual aspect of football. One of the latest events is the dismissal of Trabzonspor Coach Ünal Karaman after the first half of the 2019-2020 season by a political request, according to the allegations. The outrage of Trabzonspor fans after the dismissal of Karaman was Turkey's agenda on the social media and brought many unanswered questions [20,21]. Politicians, who step in for club debts for the sake of political interest, are basically match-fixing because they provide unfair profits for the clubs. In this case, other clubs (managers, footballers and fans) have a negative attitude towards both the team about unfair earnings and the political identity who allegedly supported the team. The farther politicians stay away from the club management, the cleaner and fairer sports competitions will become [22,23].

Play-off games were played for the first time in 2012-2013 Super League. Yildırım Demirören was the president of the Beşiktaş Football Club at the time and said "Football family has one goal; to make our fallen football rise again. This is the first task of every football lover. Fans of all of the clubs need to support both broadcasters and clubs by buying shirts and decoders.". After this statement, play-off games were requested from TFF with only financial benefits from the ticket sales of the eight teams, broadcasting revenues and betting games in mind. Out of all the clubs only Galatasaray presented a negative opinion on this subject [24-25]. What would happen to all the hard work of Galatasaray Football Club which ranked first in the league that season and the support of its passionate fans if they were to lose the championship during play-off games which were played for the sake of advertising, betting and live broadcasting revenues [26-27]?

After the first Covid-19 case was confirmed in Turkey on March 11, 2020 Nihat Özdemir, president of Turkish Football Federation made a statement that "All football games will be played without fans until 30th April" [28]. After the Galatasaray - Beşiktaş derby match which was played on the 26th week of Super League on March 15, 2020, president of Galatasaray F.C. Fatih Terim said in a press conference "Schools are closed; assembly meetings, all activities, development leagues, European leagues, NBA in USA, tennis matches are either canceled or postponed. Our health is at stake. Our lives are at stake. There are a 1000 of us in here. Nine matches mean $9000-$ 1000 individuals. With what scientific approach and precautions do you let this game be played? Association of Footballers, Association of Coaches, Association of
Referees are all silent and cannot speak. They won't be able to speak until they are unionized." [29]. After the game, TFF vice president and Chief Executive Officer wrote a letter to Özdemir regarding the failure to postpone the games [30]. He was asked to resign for this latter. On March 23, first Abdurrahim Albayrak, the second president of Galatasaray F.C., then Fatih Terim were tested positive for Covid-19 [31]. Did broadcasting and betting companies ask for the games to be played risking the lives of many, similar to what happened in 2012.

As a result of public pressure, Turkish Super League was postponed with a decision taken on Thursday, March 19, 2019 [32].

\section{Suggestions}

The financial fair play applied to the sports economy, which has become a major industry especially with the spread of technology and virtual betting since the early 2000s, should be expanded in scope and narrowed in budget limit. Thus, the financial gap between the teams disappears and fairer sports competitions can be watched. Otherwise, surprises, traumas and sadness caused by undeserved successes in football due to match fixing may continue to be experienced. People should come together for stronger professional compound sports organizations such as "Professional Footballers Union".

Given that match fixing is theft and a moral decay, the teaching of moral and ethical concepts should be included in the curricula starting from pre-school period so that the generations who protect their moral values can fix this decay.

TFF must first review its precautions and punishments against playing betting games and match fixing, and then increase its practices and sanctions further.

Unless the sport is left to the athletes, the club operations to the managers and there are no supporters in all the other titles, the match fixing will continue to change name and create outrages between the fans and the club.

The role of betting companies cannot be disregarded in the cases of play-off matches and matches of the 26th week. With a unionized sports community, and the farther the politics and betting games are away from sports, a better quality that football community will have, will be reliable and will value human life.

\section{REFERENCES}

[1] Şeker FS., Şahin M. The Communal Effects of Bet Match Fixing In Football. European Journal of Education Studies. ISSN: 2501 - 1111, Volume 4, Issue 11, 2018.

[2] Online Available: www.betsbahis247.com/canli-bahis, Online available from www.betsbahis247.com 
[3] Online Available: www.sportoto.gov.tr/turkiyede-spor-toto. aspx, Online available from

[4] Online Available: www.haberturk.com/son-dakika-iddaa-ih alesinde-yeni-gelisme-2388382-ekonomi, Online available from www.haberturk.com

[5] Kurt M, Atayman V, Kurultay T. "Show" in the arena is the past and present of modern sports, 1st edition, Sorun Publications, İstanbul, 1997.

[6] Akşar T. Industrial football, 1st edition, Fora iletişim Hiz. Ltd. Şti., İstanbul, 2005.

[7] Şahin M. Sports Ethics and Problems, 2nd Edition Evrensel, Edition Publications, İstanbul: 2009.

[8] Simson VYV, Jennings A doping-the lords of the rings, 1st edition, Milliyet Yayın A.ş., İstanbul, 1994.

[9] Gürbüz S, Şahin F. Research methods in social sciences, 1st edition, Seçkin Yayıncılık, Ankara, 2016.

[10] Online Available: https://www.tff.org/Resources/TFF/Docu ments/TALIMATLAR/Futbol-Disiplin-Talimati.pdf, Online available from https://www.tff.org/

[11] Online Available: https://www.mevzuat.gov.tr/MevzuatMet in/1.5.6222.pdf, Online available from https://www.mevzua t.gov.tr/

[12] Online Available: https://www.tbmm.gov.tr/develop/owa/tu tanak_g_sd.birlesim_baslangic?P4=21057\&P5=H\&page $1=$ 21 \&page $2=21$, Online available from https://www.tbmm.go v.tr

[13] Online Available: https://www.ntv.com.tr/turkiye/aziz-yildi rim-tutuklandi,vnOIMBihpUqc1f7MtDNj-w, Online available from https://www.ntv.com.tr

[14] Online Available: https://www.evrensel.net/haber/190122/s ike-sorusturmasi-dalgasi-surdu, Online available from https://www.evrensel.net

[15] Online Available: https://www.yeniakit.com.tr/haber/avrup ada-sike-skandali-gozaltina-alindilar-528288.html, Online available from https://www.yeniakit.com.tr

[16] Online Available:https://www.bbc.com/turkce/haberler/200 9/11/091120 germany football, Online available from https://www.bbc.com

[17] Online Available: https://www.cnnturk.com/spor/futbol/asy ada-sike-depremi-22-kisi-futboldan-men-edildi, Online available from https://www.cnnturk.com

[18] Hanbay E. The role of public relations activities in creating trust: Match fixing crisis in 2010-2011 Turkish Super Leauge and loss of trust. TC İstanbul University, İstanbul, 2012.
[19] Ceylan B. Football, politics and media relations in Turkey: A critical view to the Match-Fixing Operation news in 3 July 2011, TC Atatürk University, Erzurum, 2016.

[20] Online Available: www.acunn.com/spor/unal-karaman-ned en-gitti-iste-trabzonspor-da-yasanan-unal-karaman-krizinin -ayrintilari-1153556-haber, Online available from www.acu nn.com

[21] Online Available: https://tele1.com.tr/trabzonsporda-unal-k araman-bilmecesi-berat-albayrak-mi-gorevden-aldirdi-1158 53/, Online available from https://tele1.com.tr/

[22] Online Available:https://odatv4.com/futbol-camiasinda-sok -gelisme-29121925.html, Online available from https://odat v4.com

[23] Online Available: https://tele1.com.tr/unal-karamanin-istifa sinda-siyaset-eli-bu-fotograf-nedeniyle-mi-gonderildi-1149 82/, Online available from https://tele1.com.tr/

[24] Online Available:https://www.fanatik.com.tr/super-ligde-pl ay-off-sistemi-235091, Online available fromhttps://www.f anatik.com.tr/

[25] Online Available: https://www.cnnturk.com/2011/spor/futb ol/08/23/toplantidan.play.off.karari.cikti/627036.0/index.ht $\mathrm{ml}$, Online available from https://www.cnnturk.com

[26] Online Available: https://m.webaslan.com/futbol/son-10-yil da-tffnin-galatasaraya-yaptiklariSXGLQ5230SXQ?sira=2, Online available from https://m.webaslan.com/

[27] Online Available: https://www.haberturk.com/spor/futbol/h aber/741638-sampiyon-galatasaray, Online available from https://www.haberturk.com/

[28] Online Available: https://www.trtspor.com.tr/haber/futbol/s uper-lig/tff-baskani-nihat-ozdemirden-erteleme-aciklamasi205542.html, Online available from https://www.trtspor.co m.tr

[29] Online Available: https://skor.sozcu.com.tr/2020/03/15/fati h-terim-derbi-sonrasi-sert-konustu-hic-mi-allahtan-korkmu yorsunuz-1465368/, Online available from https://skor.sozc u.com.tr

[30] Online Available: https://www.cnnturk.com/spor/futbol/tffbaskan-vekili-bahcivan-istifa-etti, Online available from https://www.cnnturk.com

[31] Online Available: https://www.takvim.com.tr/spor/2020/03/ 24/cimbomda-coronavirus-depremi-fatih-terim-ve-abdurrah im-albayrakin-testi-pozitif-cikti, Online available from https://www.takvim.com.tr

[32] Online Available: https://www.hurriyet.com.tr/sporarena/su per-ligde-maclar-ertelendi-lig-ne-zaman-baslayacak-41472 798, Online available from https://www.hurriyet.com.tr 